Volume 7 No. 2, Juli-Desember 2020

P-ISSN: 2406-808X // E-ISSN: 2550-0686

https://journal.iainlangsa.ac.id/index.php/ikhtibar

https://doi.org/10.32505/ikhtibar.v7i2.617

\title{
PERKEMBANGAN JIWA BERAGAMA PADA MASA ANAK-ANAK
}

\author{
Muhibuddin, Junaidi \\ Institut Agama Islam Negeri Langsa
}

\begin{abstract}
Abstrak
Masa kanak-kanak adalah masa dimana serang individu mulai dapat berinteraksi dengan individu yang lainya, pada masa inilah sebenarnya masa emas dimana seseorang di perkenalkan dengan agama, karena di masa ini anak yang secara pikiran belum terlalu kritis dalam arti setiap apa yang di berikan oleh orang tuanya akan di terimanaya. Perkembangan jiwa beragama pada anak-anak umumnya adalah perkembangan yang masih awal, tetapi sebenarnya sebelum masa anak- anak pun seorang anak telah mendapatkan sebuah pendidikan tentang keagamaan, yaitu dalam kandungan, masa pranatal dan masa bayi. Walaupun pada saat itu penerimaan pendidikan agama itu belum dapat diberikan secara langsung misalnya dalam kandungan, seorang janin hanya bisa menerima rangsangan atau respon dari sang ibu, ketika ibu sedang sholat mungkin atau mengerjakan perintah - perintah agama lainnya, begitu juga pada saat bayi dilahirkan, ia hanya menerima rangsangan dari luar misalnya pada saat sang bayi di azan kan. nah dari itu kita bisa menyimpulkan bahwa masa anak- anak bukan lah masa yang paling awal mendapatkan pendidikan keagamaan.
\end{abstract}

Kata Kunci: Perkembangan Jiwa, Agama, Anak

\begin{abstract}
Abstrac
Childhood is a period where individual attacks begin to be able to interact with other individuals, this is actually the golden age where someone is introduced to religion, because at this time children who are not in their minds are not too critical in the sense of everything that is given by people. his parents will be accepted. The development of the religious spirit in children is generally still early development, but actually even before childhood a child has received education about religion, namely in the womb, prenatal and infancy. Even though at that time the acceptance of religious education could not be given directly, for example in the womb, a fetus could only receive stimulation or a response from the mother, when the mother was praying or doing other religious orders, as well as when the baby was born, she only receive stimuli from outside, for example when the baby is azan. from that, we can conclude that childhood is not the earliest period to get religious education
\end{abstract}

\section{A. Pendahuluan}

Sebuah kata bijak menyebutkan bahwa masa sekarang di pengaruhi oleh masa yang terdahulu, begitu juga dengan sifat keberagamaan pada manusia, bahwasanya tingkat kesadaran agama pada tiap manusia sangat di pengaruhi pada masa kecilnya. Manusia 
dilahirkan di dunia ini dalam keadaan lemah, fisik maupun psikis. Walaupun dalam keadaan yang demikian ia telah memiliki kemampuan bawaan yang bersifat laten. Potensi bawaan ini memerlukan pengembangan melalui bimbingan dan pemeliharaan yang mantap lebihlebih pada usia dini.

Fisik atau jasmani manusia baru akan berfungsi secara sempurna jika dipelihara dan dilatih. Akal dan fungsi mental lainnya pun baru akan berfungsi jika kematangan dan pemeliharaan serta bimbingan dapat diarahkan kepada pengeksplorasian perkembangannya. Kemampuan itu tidak dapat dipenuhi secara sekaligus melainkan melalui pentahapan. Demikian juga perkembangan agama pada diri anak.

Masa kanak-kanak adalah masa dimana serang individu mulai dapat berinteraksi dengan individu yang lainya, pada masa inilah sebenarnya masa emas dimana seseorang di perkenalkan dengan agama, karena di masa ini anak yang secara pikiran belum terlalu kritis dalam arti setiap apa yang di berikan oleh orang tuanya akan di terimanaya.

Dalam masa perkembangan keagamanya seorang individu, terdapat faktor faktor yang sangat mempengaruhi keagamaanya, faktor itu dapat berasal dari dalam dirinya atau bersal dari faktor luar. Dalam makalah kali ini penulis akan berusaha menjelaskan proses perkembangan jiwa agama pada anak.

\section{B. Timbulnya Jiwa Keagamaan pada Anak}

Manusia dilahirkan dalam keadaan lemah, fisik maupun psikis. Walaupun dalam keadaan yang demikian ia telah memiliki kemampuan bawaan yang bersifat laten. Potensi bawaan ini memerlukan pengembangan melalui bimbingan dan pemeliharaan yang mantap lebih-lebih pada usia dini.

Perkembangan jiwa beragama pada anak-anak umumnya adalah perkembangan yang masih awal, tetapi sebenarnya sebelum masa anak- anak pun seorang anak telah mendapatkan sebuah pendidikan tentang keagamaan, yaitu dalam kandungan, masa pranatal dan masa bayi. Walaupun pada saat itu penerimaan pendidikan agama itu belum dapat diberikan secara langsung misalnya dalam kandungan, seorang janin hanya bisa menerima rangsangan atau respon dari sang ibu, ketika ibu sedang sholat mungkin atau mengerjakan perintah - perintah agama lainnya, begitu juga pada saat bayi dilahirkan, ia hanya menerima rangsangan dari luar misalnya pada saat sang bayi di azan kan. nah dari itu kita bisa menyimpulkan bahwa masa anak- anak bukan lah masa yang paling awal mendapatkan pendidikan keagamaan ${ }^{1 .}$

Timbulnya jiwa keagamaan pada anak kemantapan dan kesempurnaan perkembangan potensi manusia yang dibawanya sejak lahir baik jasmani maupun rohani memerlukan pengembangan melalui pemeliharaan dan latihan. Jasmaninya baru akan berfungsi secara sempurna jika dipelihara dan dilatih. Akal dan fungsi mental lainnya pun baru akan menjadi baik dan berfungsi kematangan dan pemeliharaan serta bimbingan dapat diarahkan kepada pengeksplorasian perkembangannya. ${ }^{2}$

Kesemuanya itu tidak dapat dipenuhi secara sekaligus melainkan melalui pertahapan. Demikian juga perkembangan agama pada anak.

Menurut beberapa ahli anak dilahirkan bukanlah sebagai makhluk yang religius. Anak yang baru dilahirkan lebih mirip binatang dan malahan mereka mengatakan anak seekor kera lebih bersifat kemanusiaan daripada bayi manusia itu sendiri. Selain itu ada pula yang berpendapat sebaliknya bahwa anak sejak dilahirkan telah membawa fitrah keagamaan. Fitrah itu baru berfungsi dikemudian hari melalui proses bimbingan dan latihan

1 http://delsajoesafira.blogspot.com/perkembangan-jiwa-beragama-pada-anak-anak.html

2 Jalaluddin, Psikologi Agama (Jakarta: PT Raja Grafindo Persada, 2003), hal. 63-66 
setelah berada pada tahap kematangan. Ada beberapa teori mengenai pertumbuhan agama pada anak antara lain:

1. Rasa ketergantungan (Sense of Depende)

Teori ini dikemukakan oleh Thomas melalui teori Four Wishes. Menurutnya, manusia dilahirkan ke dunia ini memiliki empat keinginan, yaitu:

a) Keinginan untuk perlindungan (security)

b) Keinginan akan pengalaman baru (new experience)

c) Keinginan untuk mendapat tanggapan (response)

d) Keinginan untuk dikenal (recognation)

Berdasarkan kenyataan dan kerjasama dari keempat keinginan itu, maka bayi sejak dilahirkan hidup dalam ketergantungan. Melalui pengalaman-pengalaman yang diterimanya dari lingkungan itu kemudian terbentuklah rasa keagamaan pada diri anak.

2. Instink keagamaan

Menurut Woodworth, bayi yang dilahirkan sudah memiliki beberapa instink diantaranya instink keagamaan. Misalnya instink social pada anak sebagai potensi bawaannya sebagai makhluk homo socius, baru akan berfungsi setelah anak dapat bergaul dan berkemampuan untuk berkomunikasi. Jadi instink social itu tergantung dari kematangan fungsi lainnya. Demikian pula instink keagamaan.

\section{Proses Timbulnya Kepercayaan Kepada Tuhan Dalam Diri Anak}

Menurut Zakiyyah Darajat, anak mulai mengenal Tuhan melalui proses:

1. Melalui bahasa, yaitu dari kata-kata orang yang ada dalam lingkungannya yang pada mulanya diterimanya secara acuh tak acuh.

2. Setelah itu karena melihat orang-orang dewasa menunjukkan rasa kagum dan takut terhadap Tuhan, maka mulailah timbul dalam diri anak rasa sedikit gelisah dan ragu tentang sesuatu yang ghaib yang tidak dapat dilihatnya itu (Tuhan).

3. Rasa gelisah dan ragu itu mendorong anak untuk ikut membaca dan mengulang kata Tuhan yang diucapkan oleh orang tuanya.

4. Dari proses itu, tanpa disadari anak lambat laun "pemikiran tentang Tuhan" masuk menjadi bagian dari kepribadian anak dan menjadi objek pengalaman agamis.

Jadi pada awalnya Tuhan bagi anak-anak merupakn nama dari sesuatu yang asing yang tidak dikenalnya, bahkan diragunakan kebaikannya. Pada tahap awal ini anak tidak mempunyai perhatian pada Tuhan, hal ini dikarenakan anak belum mempunyai pengalaman yang mempunyai pengalaman yang membawanya kesana (baik pengalaman yang menyenangkan atau pengalaman yang menyusahkan).

Perhatian anak pada Tuhan tumbuh dan dan berkembang setelah ia menyaksikan reaksi orang-orang disekelilingnya tentang Tuhan yang disertai oleh emosi dan perasaan tertentu.

\section{Bagaimana pengalaman awal anak-anak tentang Tuhan ${ }^{3}$ ?}

Menurut Zakiyyah Darajat, pengalaman awal anak-anak tentang Tuhan biasanya tidak menyenangkan, karena Tuhan merupakan ancaman bagi integritas kepribadiannya. Oleh sebab itu maka perhatian anak tentang Tuhan pada permulaannya merupakan sumber kegelisahan atau ketidaksenangannya. Hal inilah yang menyebabkan anak sering bertanya tentang zat, tempat dan perbuatan Tuhan. Pertanyaan itu bertujuan untuk mengurangkan kegelisahannya. Lalu kemudian sesudah itu timbul keinginan untuk menentangnya atau mengingkarinya.

3 Dradjat Zakiah, Ilmu jiwa agama, cetakan ke 17, (Jakarta: Bulan Bintang, 2005), hal 43-45 
Jadi, pemikiran tentang Tuhan adalah suatu pemikiran tentang kenyatan luar, sehingga hal itu disukai oleh anak. Namun untuk melanjutkan pertumbuhan dan menyesuaikan diri dengan kenyataan itu, anak harus menderita dan mendapatkan sedikit pengalaman pahit, sehingga akhirnya ia menerima pemikiran tentang Tuhan setelah diingkariya.

Menurut Teori Freud, Tuhan bagi anak-anak tidak lain adalah orang tua yang diproyeksikan. Jadi Tuhan pertama anak adalah orang tuanya. Dari lingkungan yang penuh kasih saying yang diciptakan oleh orang tua, maka lahirlah pengalaman keagamaan yang mendalam.

\section{Sifat-Sifat Agama Pada Anak-Anak}

Memahami konsep keagamaan pada anak-anak berarti memahami sifat agama pada anak-anak. Sesuai dengan ciri yang mereka miliki, maka sifat agama pada anak-anak tumbuh mengikuti pola ideas concept on outhority. Ide keagamaan pada anak sepenuhnya autoritaruis, maksudnya konsep keagamaan pada diri mereka dipengaruhi oleh faktor dari luar diri mereka. Hal tersebut dapat dimengerti karena anak sejak usia muda telah terlihat, mempelajari hal-hal yang berada diluar diri mereka. Mereka telah melihat dan mengikuti apa-apa yang dikerjakan dan diajarkan orang dewasa dan orang tua mereka tentang sesuatu yang berhubungan dengan kemashlahatan agama. Orang tua mempunyai pengaruh terhadap anak sesuai dengan prinsif dengan eksplorasi yang mereka miliki. Dengan demikian ketaatan kepada ajaran agama merupakan kebiasaan yang menjadi milik mereka yang mereka pelajari dari para orang tua maupun guru mereka. Bagi mereka sangat mudah untuk menerima ajaran dari orang dewasa walaupun belum mereka sadari sepenuhnya manfaat ajaran tersebut. Berdasarkan hal itu, maka bentuk dan sifat agama pada diri anak dapat dibagi atas: 1. Unreflective (tidak mendalam)

Dalam penelitian Machion tentang sejumlah konsep ketuhanan padadiri anak $73 \%$ mereka menganggap Tuhan itu bersifat seperti manusia. Dengan demikian, anggapan mereka terhadap ajaran agama dapat saja mereka terima dengan tanpa kritik. Kebenaran yang mereka terima tidak begitu mendalam sehingga cukup sekedarnya saja dan mereka sudah merasa puas dengan keterangan yang kadang-kadang kurang masuk akal. Meskipun demikian pada beberapa orang anak terdapat mereka yang memiliki ketajaman pikirang untuk menimbang pendapat yang mereka terima dari orang lain.

\section{Egosentris}

Anak memiliki kesadaran akan diri sendiri sejak tahun pertama usia perkembangannya dan akan berkembang sejalan dengan pertambahan pengalamannya. Apabila kesadaran akan diri itu mulai subur pada diri anak, maka akan tumbuh keraguan pada rasa egonya. Sehubungan dengan hal itu, maka dalam masalah keagamaan anak telah menonjolkan kepentingan dirinya dan telah menuntut konsep keagamaan yang mereka pandang dari kesenangan pribadinya.

\section{Anthromorphis}

Pada umumnya konsep mengenai ketuhanan pada anak berasal dari hasil pengalamannya dikala ia berhubungan dengan orang lain. Tapi suatu kenyataan bahwa konsep ketuhanan mereka tampak jelas menggambarkan aspek-aspek kemanusiaan. Melalui konsep yang terbentuk dalam pikiran mereka menganggap bahwa perikeadaan Tuhan itu sama dengan manusia. Pekerjaan Tuhan mencari dan menghukum orang yang berbuat jahat. 4. Verbalis dan ritualis

Dari kenyataan yang kita alami ternyata kehidupan agama pada anak-anak sebagian besar tumbuh mula-mula secaraverbal (ucapan). Mereka mengahapal secara verbal kalimat- 
kalimat keagamaan dan selain itu pula dari amaliah yang mereka laksanakan berdasarkan pengalaman menurut tuntunan yang diajarkan kepada mereka.

\section{Imitatif}

Dalam kehidupan sehari-hari dapat kita saksikan bahwa tindak keagamaan yang dilakukan oleh anak-anak pada dasarnya diperoleh dari meniru. Berdo'a dan shalat misalnya mereka laksanakan karena hasil melihat perbuatan di lingkungan, baik berupa pembiasaan ataupun pengajaran yang intensif. Para ahli jiwa menganggap, bahwa segala hal anak merupakan peniru yang ulung. Sifat peniru ini merupakan modal yang positif dalam pendidikan keagamaan pada anak.

\section{Rasa heran}

Rasa heran dan kagum merupakan tanda dan sifat keagamaan yang terakhir pada anak. Berbeda dengan rasa kagum yang ada padaorang dewasa, maka rasa kagum pada anak ini belum bersifat kritis dan kreatif. Mereka hanya kagum terhadap keindahan lahiriyah saja. Hal ini merupakan langkah pertama dari pernyataan kebutuhan anak akan dorongan untuk mengenal sesuatu yang baru (new experience). Rasa kagum mereka dapat disalurkan melalui cerita-cerita yang menimbulkan rasa takjub. ${ }^{4}$

\section{E. Perkembangan Agama pada Anak}

Melalui penelitian Ernest Harms perkembangan agama anak-anak itu melalui mengatakan bahwa perkembangan agama pada anak-anak itu melalui tiga tingkatan, yaitu ${ }^{5}$ : 1. The Fairy Tale Stage (tingkat dongeng)

Tingkatan ini dimulai pada anak berusia 3-6 tahun. Pada tingkatan ini konsep mengenai Tuhan lebih banyak dipengaruhi oleh fantasi dan emosi. Pada tingkat perkembangan ini anak menghayati konsep ke-Tuhanan sesuai dengan tingkat perkembangan intelektualnya. Kehidupan masa ini masih banyak dipengaruhi kehidupan fantasi hingga dalam menanggapi agama pun anak masih menggunakan konsep fantastis yang diliputi oleh dongeng-dongeng yang kurang masuk akal, Perhatian anak lebih tertuju pada para pemuka agama dari pada isi ajaran agamanya.

2. The Ralistic Stage (tingkat kepercayaan)

Pada tingkat ini pemikiran anak tentang Tuhan sebagai bapak beralih pada Tuhan sebagai pencipta. Hubungan dengan Tuhan yang pada awalnya terbatas pada emosi berubah pada hubungan dengan menggunakan pikiran atau logika.

Pada masa ini, ide ketuhanan anak sudah mencerminkan konsep-konsep yang berdasarkan kepada kenyataan (realis). Konsep ini timbul melalui lembaga-lembaga keagamaan dan pengajaran agama dari orang dewasa lainnya. Pada masa ini ide keagamaan pada anak didasarkan atas dorongan emosional, hingga mereka dapat melahirkan konsep Tuhan yang formalis. Berdasarkan hal itu maka pada masa ini anak tertarik dan senang pada lembaga keagamaan yang mereka lihat dikelola oleh orang dewasa dalam lingkungan mereka.

Pada tahap ini teradapat satu hal yang perlu digaris bawahi bahwa anak pada usia 7 tahun dipandang sebagai permulaan pertumbuhan logis, sehingga wajarlah bila anak harus diberi pelajaran dan dibiasakan melakukan shalat pada usia dini dan dipukul bila melanggarnya.

\section{The Individual Stage (Tingkat Individu-Usia Remaja)}

Pada tingkat ini anak telah memiliki kepekaan emosi yang tinggi, sejalan dengan perkembangan usia mereka. Konsep keagamaan yang diindividualistik ini terbagi menjadi tiga golongan:

$4 \mathrm{Ibid}$.

5 Jalaluddin, Psikologi agama, (PT RajaGarfindo Persada: Jakarta, 1998), hal 66 
1) Konsep ketuhanan yang konvensional dan konservatif dengan dipengaruhi sebagian kecil fantasi.

2) Konsep ketuhanan yang lebih murni, dinyatakan dengan pandangan yang bersifat personal (perorangan) ${ }^{6}$.

3) Konsep ketuhanan yang bersifat humanistik. Agama telah menjadi etos humanis pada diri mereka dalam menghayati ajaran agama. Perubahan ini setiap tingkatan dipengaruhi oleh factor entern yaitu perkembangan usia dan faktor ekstern berupa pengaruh luar yang dialaminya. ${ }^{7}$

\section{F. Pendekatan Pembinaan Agama pada Anak}

Dalam pembinaan agama pada diri pribadi anak sangat diperlukan pembiasaan dan latihan-latihan yang cocok dan yang sesuai dengan perkembangan jiwanya. Karena pembiasaan dan latihan-latihan tersebut akan membentuk sikap tertentu pada anak, yang lambat laun sikap itu akan bertambah jelas dan kuat, akhirnya tidak tergoyahkan lagi karena telah masuk menjadi bagian dari pribadinya.

Untuk membina agar anak-anak mempunyai sifat terpuji tidaklah mungkin dengan penjelasan saja, akan tetapi perlu membiasakannya untuk melakukan yang baik yang diharapkan nanti dia akan mempunyai sifat-sifat itu, dan menjauhi sifat-sifat tercela. Kebiasaan dan latihan itulah yang membuat anak cenderung melakukan perbuatan yang baik dan meninggalkan yang kurang baik.

Demikian pula dengan pendidikan agama, semakin kecil umur anak, hendaknya semakin banyak latihan dan pembiasaan agama yang dilakukan pada anak, dan semakin bertambah umur anak, hendaknya semakin bertambah pula penjelasan dan pengertian tentang agama itu sesuai dengan perkembangan yang dijelaskannya.

Pembentukan sikap, pembinaan moral dan pribadi pada umumnya, terjadi melalui pengalaman sejak kecil. Pendidik atau pembina yang pertama adalah orang tua, kemudian guru. Sikap anak terhadap agama dibentuk pertama kali di rumah melalui pengalaman yang didapat dari orang tuanya, kemudian dissempurnakan dan diperbaiki oleh guru disekolah maupun ditempat pengajian seperti masjid, mushola, TPQ dan madrasah diniyyah.

Latihan- latihan yang menyangkut ibadah seperti sembahyang, do'a, membaca alQur'an, sopan santun, dan lain sebagainya, semua itu harus dibiasakan sejak kecil, sehingga lama-kelamaan akan tumbuh rasa senang dan terbiasa dengan aktifitas tersebut tanpa ada rasa terbebani sedikitpun. Latihan keagamaan yang menyangkut akhlak dan sosial atau hubungan manusia dengan manusia yang sesuai dengan ajaran agama juga tidak hanya dijelaskan dengan kata-kata, latihan disini diberikan melalui perilaku yang terpuji, baik itu dari orang tua maupun guru, seperti pemberian sedekah kepada fakir miskin, berkurban, menolong terhadap sesama, dan sebagainya. Oleh karena itu guru agama mempunyai kepribadian yang dapat mencerminkan ajaran agama seperti apa yang diajarkan kepada anak didiknya.

Kepercayaan kepada Tuhan dan agama pada umumnya tumbuh melalui latihan dan pembiasaan sejak kecil, dengan kata lain pembiasaan dalam pendidikan pada anak sangat penting, terutama pembentukan pribadi akhlak dan agama pada umumnya. Hal itu dikarenakan pembiasaan-pembiasaan tersebut akan memasukkan unsur-unsur positif pada pribadi anak yang sedang tumbuh. Semakin banyak pengalaman agama yang didapatkanya melalui pembiasaan itu, maka akan banyak pula unsur-unsur agama dalam pribadinya, dan

6 Dradjat Zakiah, Ilmu jiwa agama, cetakan ke 17, Jakarta: Bulan Bintang, 2005. Hal, 50-55 7 Ibid, h. 66-70 
semakin mudah dia memahami sebuah ajaran agama yang akan dijelaskan oleh guru agamanya di kemudian hari.

Secara rinci, pembinaan agama kepada anak yang sesuai dengan sifat keberagamaan anak maka dapat dilakukan melalui beberapa pendekatan, antara lain:

1. Pembinaan agama lebih banyak bersifat pengalaman langsung seperti shalat berjamaah, bersedekah, zakat, berkurban, meramaikan hari raya dengan menggemakan takbir, dan lain sebagainya. Pengalaman agama secara langsung tersebut dapat ditambah dengan penjelasan sekedarnya saja atau pesan-pesan yang disampaikan melalui dongeng, cerita, main drama, nyanyian, permainan sehingga tidak membabani mental maupun pikiran mereka.

2. Kegiatan agama disesuaikan dengan kesenangan anak-anak, mengingat sifat agama masih bersifat egosentris. Sehingga model pembinaan agama bukan mengikuti kemauan orang tua maupun guru saja, melainkan harus dengan banyak variasi agar anak tidak bosan. Untuk itu, orang tua dan guru harus memiliki banyak ide dan kreativitas tentang strategi dan teknik pembinaan agama, sehingga setiap saat bisa berganti-ganti pendekatan dan metode walaupun materi yang disampaikan boleh jadi sama.

3. Pengalaman agama anak, selain didapat dari orang tua, guru dan teman-temannya, mereka juga belajar dari orang yang disekitarnya yang tidak mengajarinya secara langsung. Untuk itu pembinaan agama anak juga penting dilakukan melalui pembauran secara langsung dengan masyarakat luas yang terkait dengan kegiatan agama seperti waktu mengikuti sholat jum'at, tarawih, hari raya, maupun kegiatan lainnya. Dengan mengajak anak sekali waktu berbaur secara langsung dengan masyarakat yang melakukan peribadatan maka anak akan semakin termotivasi untuk menirukan perilaku-perilaku agama yang dilakukan oleh masyarakat umum. Hal ini perlu dilakukan mengingat agama anak masih bersifat anthromorphis.

4. Pembinaan agama kepada anak juga perlu dilakukan secara berulang-ulang melalui ucapan yang jelas serta tindakan secara langsung. Seperti mengajak anak shalat, maka terlebih dahulu diajarkan mengenai hafalan bacaan-bacaan shalat secara berulang-ulang hingga anak tersebut hafal diluar kepala. Hal tersebut diiringi dengan tindakan atau praktik sholat secara langsung dan akan lebih menarik jika dilakukan bersama temantemannya. Setelah anak hafal tentang bacaan-bacaan sholat, maka seiring dengan bertambah usia, pengalaman, dan pengetahuannya barulah dijelaskan tentang syarat, rukun, serta hikmah shalat. Demikian pula pada pembinaan-pembinaan agama lainnya.

5. Mengingat sifat agama masih imitatif, maka pemberian contoh nyata dari orang tua guru dan masyarakat lingkungannya sangatlah penting. Untuk itu dalam proses pembinaan tersebut, perilaku orang tua maupun guru harus benar-benar dapat dicontoh anak baik secara ucapan maupun tindakan.

6. Perlunya melakukan kunjungan ke tempat-tempat atau pusat-pusat agama yang lebih besar kapasitasnya. Misalnya anak-anak yang tinggal di desa sesekali perlu diajak berkunjung ke masjid jami' yang ada di kota yang bangunan-bangunan dan jumlah jama'ahnya lebih besar. Atau bisa juga anak diajak berkunjung ke pondok pesantren, kampus-kampus islam, dan lain sebagainya. Selain dengan kunjungan, anak dapat diajari tentang agama melalui layar kaca televisi ataupun VCD. Pembinaan dengan cara ini sangatlah penting mengingat rasa heran dan kagum merupakan tanda dan sifat keagamaan pada anak. ${ }^{8}$

8 http://aminfuadi99.blogspot.com/2011/04/perkembangan-jiwa-keagamaan-pada-ak.html/2011/04/ perkembangan-jiwa-keagamaan-pada-anak.html 


\section{G. Kesimpulan}

Agama pada masa anak-anak terbentuk melalui pengalaman-pengalaman yang diterima dari lingkungan lalu terbentuk sifat keagamaan pada anak, Woodwort berpendapat bahwa bayi memiliki insting keagamaan, akan tetapi disanggah oleh pemikir Islam bahwa bayi tidak mempunyai insting keagamaan melainkan itu merupakan fitrah yang cenderung kearah potensi keagamaan. Tahap perkembangan keagamaan pada anak melalui tiga tahapan yaitu tingkat dongeng, tingkat kepercayaan, dan tingkat individu

Sifat Agama pada anak mengikuti pola concept on authority yaitu konsep keagamaan yang dipengaruhi oleh faktor dari luar diri mereka (anak) itu sendiri. Memahami sifat agama pada anak berarti memahami sifat agama itu sendiri.Perkembangan jiwa beragama pada anak- anak umumnya adalah perkembangan yang masih awal, tetapi sebenarnya sebelum masa anak- anak pun seorang anak telah mendapatkan sebuah pendidikan tentang keagamaan, yaitu dalam kandungan, masa pranatal dan masa bayi.

Pada awalnya Tuhan bagi anak-anak merupakn nama dari sesuatu yang asing yang tidak dikeenalnya, bahkan diragunakan kebaikannya. Perhatian anak pada Tuhan tumbuh dan dan berkembang setelah ia menyaksikan reaksi orang-orang disekelilingnya tentang Tuhan yang disertai oleh emosi dan perasaan tertentu

\section{Daftar Pustaka}

Dradjat Zakiah, Ilmu jiwa agama, cetakan ke 17, Jakarta: Bulan Bintang, 2005. Jalaluddin, Psikologi agama, PT RajaGarfindo Persada: Jakarta, 1998.

Jalaluddin, Psikologi Agama, Jakarta: PT Raja Grafindo Persada, 2003. $\mathrm{http} / / /$ delsajoesafira.blogspot.com/perkembangan-jiwa-beragama-pada-anak-anak.html http://aminfuadi99.blogspot.com/2011/04/perkembangan-jiwa-keagamaan-pada-ak.html\#! /2011/04/ perkembangan-jiwa-keagamaan-pada-anak.html. 